\title{
Electric Conductivity of Gum Arabic from Acacia Senegal
}

\author{
Leila Mokhtar \\ Assist Prof. Dept of Chem. Faculty of Education, Kordofan University (Sudan), Now at Shaqra University, (Kingdom of Saudi Arabia)
}

\begin{abstract}
Samples of Gum solutions of different concentrations were prepared by dissolved Gum powder in distilled water. The stud emphasized the effects of temperature, distance between capacitor plates, added electrolytes (NaCl) and different concentration of gum solutions on the conductive properties. The electric conductivity was $0.0 \mathrm{mS}$ at lowest concentration and minimum temperature $0.0^{\circ} \mathrm{c}$, it increased to $0.5 \mathrm{mS}$ when the temperature was increased to $90{ }^{\circ} \mathrm{c}$. When the concentration was increased to $0.3 \%$ at $0.0^{\circ} \mathrm{c}$, the conductivity increased $4.8 \mathrm{mS}$. The conductivity reached its maximum $19.5 \mathrm{mS}$ at $90^{\circ} \mathrm{c}$ and $0.3 \%$ concentration. The electric current reached its maximum value $8.0 \mathrm{~mA}$ at the concentration of $0.3 \%$ at room temperature and $1 \mathrm{~cm}$ distance between the capacitor plates. The electric current increased with increase in temperature, to reach the maximum $63 \mathrm{~mA}$ at $0.3 \%$ concentration and $90^{\circ} \mathrm{c}$. The electric current passing through the capacitor plates was reported to be $0.0 \mathrm{~mA}$ at the lowest concentration at room temperature, regardless of the distance between the two plates. Addition of $2 \%$ concentration of $\mathrm{NaCl}$ solution to gum solution of different concentration increased the conductivity, even at the lowest concentration. Increasing $\mathrm{NaCl}$ concentration showed proportional increase in the electric conductivity of gum solution.
\end{abstract}

Keyword: Gum Arabic, conductivity, current, different concentration, temperature

\section{Introduction}

Gum Arabic is a natural polymer. The major uses of gum Arabic are in food industry, pharmaceutical purposes, cosmetic, adhesives, paints, inks, lithography, textiles and medicine. $\{1,2$,$\} .$

It is the most important commercial polysaccharide gum and it is probably the oldest hydrocolloid in current use. Never the less gums as high molecular weight compounds, composed mainly of carbon, hydrogen, oxygen as sub units linked to the protein core mixed in heterogeneous manner, including some metals in ionic forms as salts of macromolecules have weak conductive properties. $\{16\}$

Gum Arabic is produced from many species of Acacia of African origin.

Chemically : A. Senegal gum is an arabiano galactanprotein composed of arabinose (17-34\%), galactose ( 32$50 \%$ ), rhamnose (11-16\%), glucuronic acid (13-19\%) and protein $(1.8-2.5 \%)$ with an optical rotation of $\left(-28^{\circ}\right.$ to $\left.-32^{\circ}\right)$. $\{1\}$

\section{The objectives of this study}

The gum Arabic as a natural polymeric mixture which could be found in solid or liquid state with variable conductance properties. Hence in this study, it is intended to investigate possibility of using the gum Arabic in the manufacture of integrated circuits IC.

\section{Literature Review}

Plant gums are organic substances obtained as exudates from fruits, trunks or branches of trees, spontaneously injury of the plant by incision of the bock or by the removal of a branch. Or after invasion by bacteria or fungi. The exudates become hard nodules ribbons or dehydrated to from protective sheath against micro-organisms. Gum often from clear glassy masses which are usually colored dark brown to pale yellow. $\{6\}$

It was used at least 4000 years ago. Ancient Egyptians used it largely in painting as an adhesive for mineral pigments. Eventually it found its way into Europe through various Arabian ports and acquired the name gum Arabic probably after its place of origin or port of export. $\{13,14\}$

\subsection{Physical and Chemical Properties of Gum}

\subsubsection{Solubility}

Regarding to the solubility the true gums are divisible into three classes

1) soluble gums that dissolve in water forming transparent solution e.g Acacia Senegal gum.

2) Insoluble gums which also absorb water but on addition of sufficient water break down into very thick transparent solution e.g tragacnth gum.

3) Half - soluble gums that partially dissolve but on addition of more water pass into soluble e.g ghatti gum. $\{20\}$

\subsubsection{Shape}

Gum collected in natural state are represented by a variety of shapes and forms, usually the fragments are irregularly globular or tear shaped. $\{23\}$

\subsubsection{Moisture}

Moisture content determines the hardness of the gum and hence the variability of densities and the amount of air entrapped during nodule formation. $\{3,22\}$

\subsubsection{Nitrogen}

The role of nitrogen and nitrogenous component in the structure, physicochemical properties and functionality of gum Arabic was recently subjected to intensive investigation . on the other hand Erick Dickens (1991) studied the emulsifying behavior of gum and concluded that there was a strong correlation between the proportion of protein in the

\section{Volume 5 Issue 2, February 2016}




\section{International Journal of Science and Research (IJSR)}

ISSN (Online): 2319-7064

Index Copernicus Value (2013): 6.14 | Impact Factor (2014): 5.611

gum and it's emulsifying stability. $\{6,10\}$

\subsubsection{Viscosity}

The viscosity can be presented in many term such as relative viscosity, specific viscosity, reduced viscosity, inherent viscosity and intrinsic viscosity. It is also presented as kinematical or dynamic viscosity, intrinsic viscosity was used to determine the molecular weight of Acacia Senegal gum. $\{4\}$

\subsubsection{Specific Rotation}

The optical activity of organic molecules is related to their structure and is a characteristic property of the substance , and thus the specific rotation is considered as the most important criterion of purity and identity of any type of gum. $\{11,21\}$

\subsubsection{Conductivity}

Conductivity is the ability, or power to transmit or conduct an electrical charge.

To measure conductivity an electronic Conductivity meter is used. Many are combined with $\mathrm{PH}$ meter so that instruments can measure $\mathrm{PH}$ and conductivity at the same time.

The unit of measurement for conductivity is expressed as the $\mathrm{Ohm}^{-1}$.

Gum Arabic is added to the fountain concentrate today. The gum function is to adhere plates and protect it from accepting ink, and also serves to protect the plate such as CMC ( Carboxy methyl cellulose) however, is still the most effective material for keeping the non - image areas of the plate clean. $\{9\}$

\section{Materials and Methods}

\subsection{Materials}

Gum sample was collected during 2004 season as natural exudates of Acacia Senegal tree in collaboration with Regional Trees Seeds Center ( Elobied ). From Demo Keya forest reserve ( 7500 Fadden) $30 \mathrm{Km}$ east of Eloied ( sandy soil, average annual rain fall $800 \mathrm{~mm}$, mean relative Humidity $34 \%$, mean evaporation $15.5 \mathrm{~mm}$ and mean minimum and maximum temperature $20^{\circ} \mathrm{C}$ and $35^{\circ} \mathrm{C}$ respectively.

\subsubsection{Preparation of sample}

Gum was dried at room temperature then cleaned by hand and kept in labeled plastic containers for analysis.

\subsection{The Primary Experiences}

Determined to use cellophane membrane but unfortunately it was not fount. Therefore bladder and polyethylene sack were used.

\subsubsection{Dispersion of sodium chloride from polyethylene} sack to distilled water

Every time accurately weighed of sodium chloride were taken, then each one was dissolved in $100 \mathrm{ml}$ of distilled water. Every concentration was put in polyethylene sack and was moved in distilled water then the conductivity was determined after every 15 minutes for 24 hour at the room temperature $\left(36^{\circ} \mathrm{C}\right.$ ) using conduct meter HI 8633 HANNA.

\subsubsection{Dispersion of sodium chloride from bladder membrane to distilled water}

Every time accurately weighed of sodium chloride were taken, then each one was dissolved in $100 \mathrm{ml}$ of distilled water. Every concentration was put in bladder membrane and was moved in $100 \mathrm{ml}$ distilled water then the conductivity was measured after every 15 minutes for 24 hour at the room temperature $\left(36^{\circ} \mathrm{C}\right)$ and the volume of sodium chloride was measured inside the Bladder membrane after 24 hours using conduct meter HI 8633 HANNA.

\subsubsection{Dispersion of gum from polyethylene sack to distilled water}

Every time accurately weighed of gum were taken, then each one was dissolved in $100 \mathrm{ml}$ of distilled water. Every concentration was put in polyethylene sack and was moved in $100 \mathrm{ml}$ of distilled water then the conductivity was determined after every 15 minutes for 24 hour at the room temperature ( $36^{\circ} \mathrm{C}$ ) using conduct meter HI 8633 HANNA.

\subsubsection{Dispersion of gum from bladder membrane to distilled water}

Accurately weighed of gum were taken every time, then each one was dissolved in $100 \mathrm{ml}$ of distilled water the conductivity to each concentration was determined. Every concentration was put in Bladder membrane $(25 \mathrm{ml})$ and was moved in $100 \mathrm{ml}$ of distilled water, the conductivity was determined after every 15 minutes at room temperature for 24 hour using conduct meter HI 8633 HANNA then the volume of gum inside the Bladder and the conductivity were measured, and the elements inside and outside the Bladder were determined using DR-4000 UV.

\subsubsection{Dispersion of gum and sodium chloride from} bladder membrane to distilled water

Accurately weighed of gum Arabic and accurately weighed of sodium chloride were taken, each one was dissolved in 100 $\mathrm{ml}$ of distilled water, after that were mixed. Then the mixture was put in Bladder membrane $(25 \mathrm{ml})$ and moved in $400 \mathrm{ml}$ of distilled water. The conductivity was determined after every 15 minutes for 24 hours. The volume of the mixture inside the Bladder and conductivity were measured before and after 24 hours.

\subsection{Physical Methods (Tool of Data Collection)}

The researcher had adopted two tools for data collection, conduct meter HI 8633 HANNA instruments and a capacitor.

\subsubsection{The conduct meter}

3.3.1.1 the relationship between the conductivity and the concentration before the addition of sodium chloride was studied. Every time accurate weighed of gum was taken. Each one dissolved in $100 \mathrm{ml}$ of distilled water. The concentrations were calculated. Then the conductivity was measured.

3.3.1.2 The relationship between the conductivity and the 


\section{International Journal of Science and Research (IJSR) \\ ISSN (Online): 2319-7064}

Index Copernicus Value (2013): 6.14 | Impact Factor (2014): 5.611

concentration after the addition of sodium chloride was studied. Accurately weighed of gum was taken every time. Each one dissolved in $100 \mathrm{ml}$ of distilled water. The concentrations were calculated, $1 \mathrm{ml}$ of sodium chloride was added to each concentration at the room temperature $\left(36^{\circ} \mathrm{C}\right)$ then the conductivity was measured.

3.3.1.3 The relation between the conductivity and the temperature was studied

Accurately weighed of gum was taken every time. Each one dissolved in $100 \mathrm{ml}$ of distilled water. The concentrations were calculated, then the conductivity was measured at different temperatures.

\subsubsection{The Capacitor}

A capacitor with two parallel plates was connected with a meter on series and with the voltmeter on parallel with electric circuit, the power supply of this circuit $12 \mathrm{volt}$, using alternating current (Ac) and alternating potential.

3.3.2.1 The relation between the current and the concentration at the different distances before the addition of sodium chloride was studied. Every time accurately weighed of gum were taken. Each one was dissolved in 100 $\mathrm{ml}$ of distilled water and the concentrations were calculated. A capacitor was filled by the concentrations of gum solution at the room temperature and the switch was closed. Then the current was measured.

3.3.2.2 The relation between the current and the concentration at the different distances after the addition of sodium chloride was studied. Every time accurately weighed of gum were taken. Each one was dissolved in 100 $\mathrm{ml}$ of distilled water and the concentrations were calculated. A capacitor was filled by the concentrations of gum solution at the room temperature, $1 \mathrm{ml}$ of sodium chloride was added to each one. Then the current was measured.

3.3.2.3 The relationship between the current and the temperature at the different concentrations was studied. Every time accurately weighed of gum were taken. Each one was dissolved in $100 \mathrm{ml}$ of distilled water, the concentrations were calculated. A capacitor was filled by the concentrations of gum solution. Then the current was measured at different temperatures.

3.3.2.4 The relationship between the current and the potential difference at different concentrations before addition of sodium chloride. Every time accurately weighed of gum were taken. Each one was dissolved in 100 $\mathrm{ml}$ of distilled water, the current and the potential difference were measured at different concentrations and then the permittivity.

3.3.2.5 The relationship between the current and the potential difference at different concentrations after addition of sodium chloride.

Every time accurately weighed of gum were taken. Each one was dissolved in $100 \mathrm{ml}$ of distilled water, $1 \mathrm{ml}$ of sodium chloride was added to each one, the current and the potential difference were measured at different concentrations and then the permittivity.

3.4 Constructing and Calibrating the Capacitors Using the Normal Graph Paper before the Addition of Sodium Chloride $\varepsilon=\frac{1}{2 \pi f x c} * \frac{d}{a}$

Where:

$\varepsilon=$ permittivity $\mathrm{f} / \mathrm{m} \varepsilon$

$\mathrm{f}=$ current frequency $\mathrm{Hz}$

$\mathrm{x}_{\mathrm{c}}=$ capacitive reactance ohm

$\pi=3.14$

$\varepsilon_{1}=0.0011373=3.571428$ per $\mathrm{cm}$

$\varepsilon_{2}=0.0022747=3.5714285$ per $\mathrm{cm}$

$\varepsilon_{3}=0.0034121=3.5714283$ per $\mathrm{cm}$

$\varepsilon_{4}=0.0045495=3.5714285$ per $\mathrm{cm}$

$\varepsilon_{5}=0.0056869=3.5714284$ per $\mathrm{cm}$

$=\left(\varepsilon_{1}+\varepsilon_{2}+\varepsilon_{3}+\varepsilon_{4}+\varepsilon_{5} / 5\right)=0.0034121=3.571428$ per $\mathrm{cm}\{$

$\bar{\varepsilon} 8,12\}$

3.5 4 Constructing and Calibrating the Capacitors Using the Normal Graph Paper after the Addition of Sodium Chloride $\varepsilon=\frac{1}{2 \pi f x c} * \frac{d}{a}$

$\varepsilon_{1}=0.0010434=3.571428$ per $\mathrm{cm}$

$\varepsilon_{2}=0.0016248=3.5714285$ per $\mathrm{cm}$

$\varepsilon_{3}=0.0026247=3.5714283$ per $\mathrm{cm} 0$

$\varepsilon_{4}=0.0022747=3.5714285$ per $\mathrm{cm}$

$\varepsilon_{5}=0.0039808=3.5714284$ per $\mathrm{cm}$

$=\left(\varepsilon_{1}+\varepsilon_{2}+\varepsilon_{3}+\varepsilon_{4}+\varepsilon_{5} / 5\right)=0.0034121=3.571428$ per $\mathrm{cm}\{$

$\bar{\varepsilon} 8,11\}$

\section{Results}

Primary tests using the polyethylene sacks show that the sacks are impermeable for ions and gum molecules. Other tests using bladder membrane, show that some ions could pass from gum solution (inside the membrane) to the distilled water outside, as well as same water from outside passed into the membrane. Therefore the conductivity of the gum Arabic solution decreases while the conductivity of the distilled water outside increases.

The following tables and figures, show the results from different measuring of the conductivity of the gum Arabic solutions under various condition such as changing temperature the distance between the capacitor plates, the amount of the electrolyte added ...etc see tables and figures (1) to (5) using alternating current ( Ac).

The results from different measuring of the current passed related to the various potential difference as fixed conductivity of the gum Arabic solution or fixed amount of electrolyte added or chosen distances between the plates of the capacitor see tables and figures (6) to (15). 


\section{International Journal of Science and Research (IJSR) \\ ISSN (Online): 2319-7064}

Index Copernicus Value (2013): 6.14 | Impact Factor (2014): 5.611

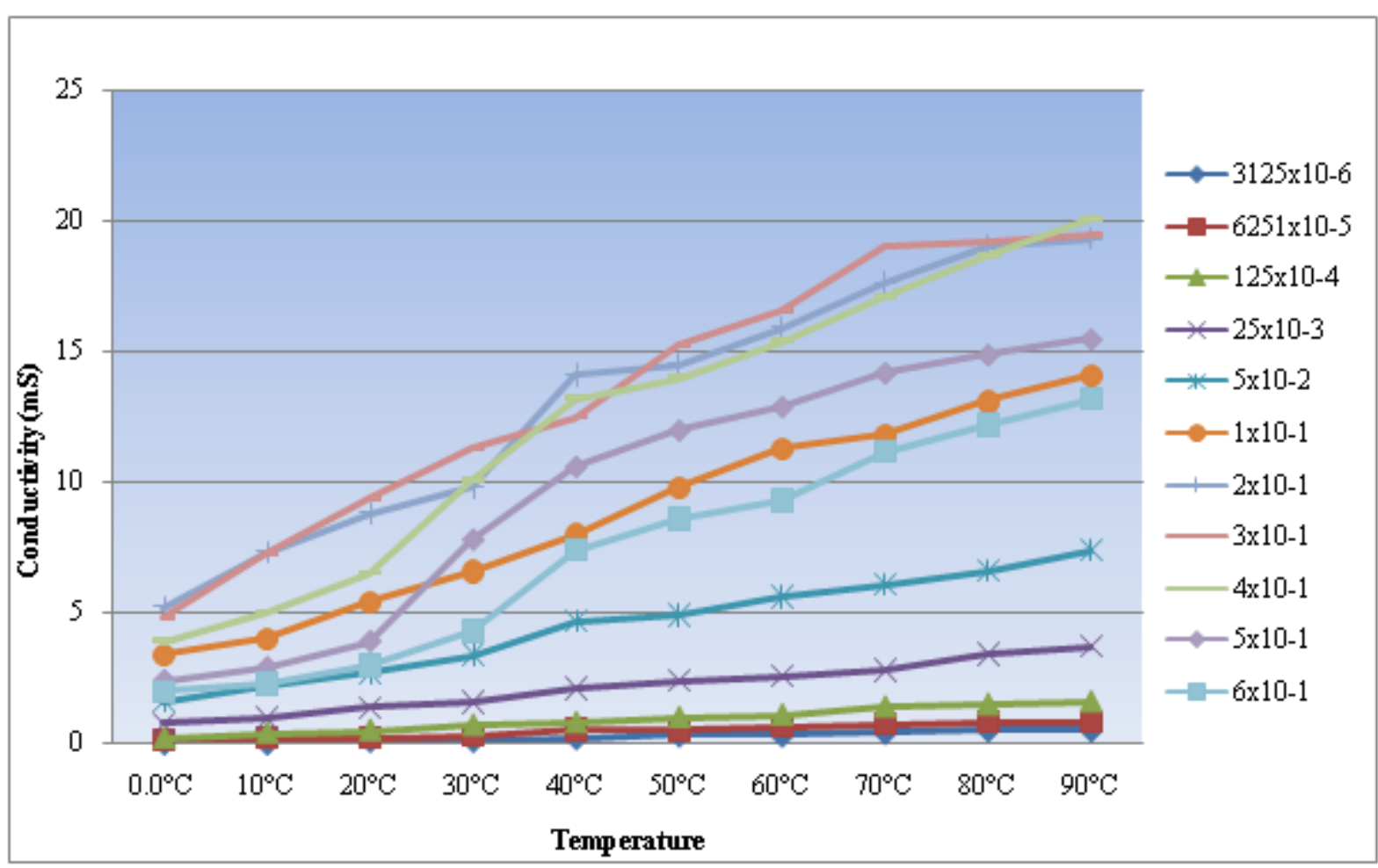

Figure 1: The Variation of conductivity $(\mathrm{mS})$ with different temperatures for different concentrations of the gum Arabic solution using conduct meter.

Each curve corresponds to concentration, using different temperatures $\left(0.0 \mathrm{c}^{\circ}-90^{\circ}\right)$.

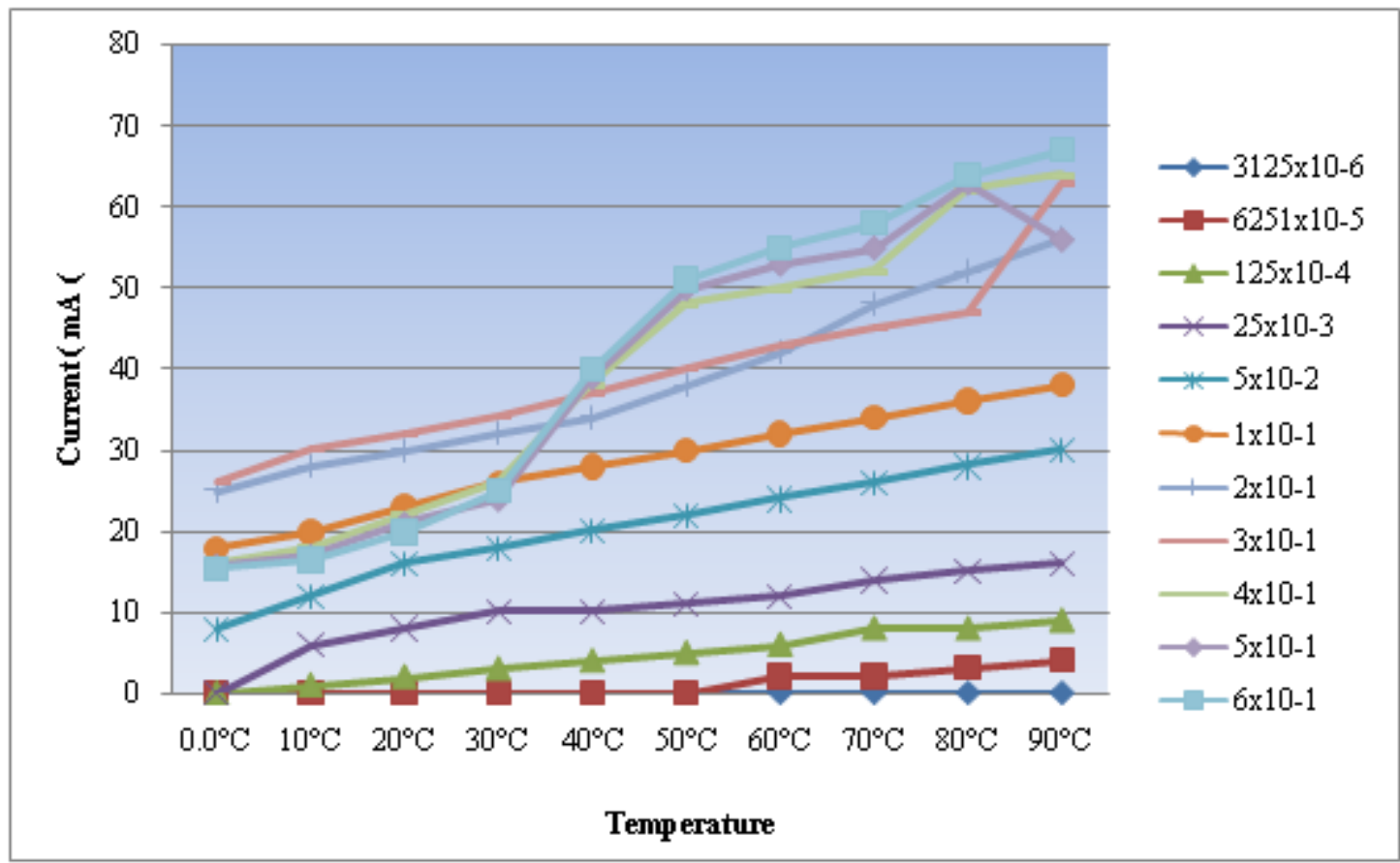

Figure 2: The Variation of current $(\mathrm{mA})$ with different temperatures for different concentrations of the gum Arabic solution using Capacitor. 


\section{International Journal of Science and Research (IJSR)}

ISSN (Online): 2319-7064

Index Copernicus Value (2013): 6.14 | Impact Factor (2014): 5.611

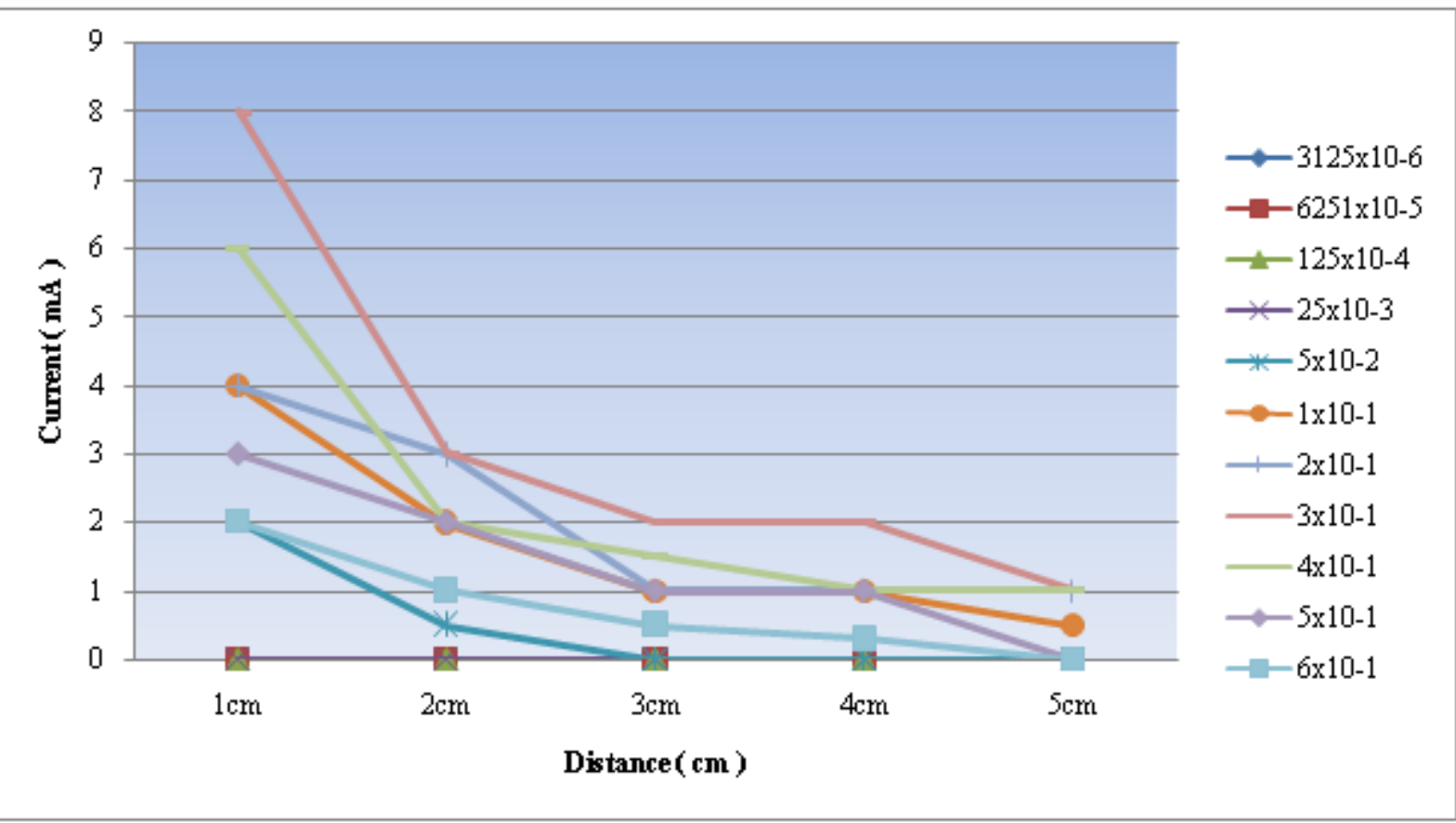

Figure 3: The Variation of current $(\mathrm{mA})$ with different distances 0 a Capacitor for different concentrations of the gum Arabic solution before the addition of $\mathrm{NaCl}(2 \%)$

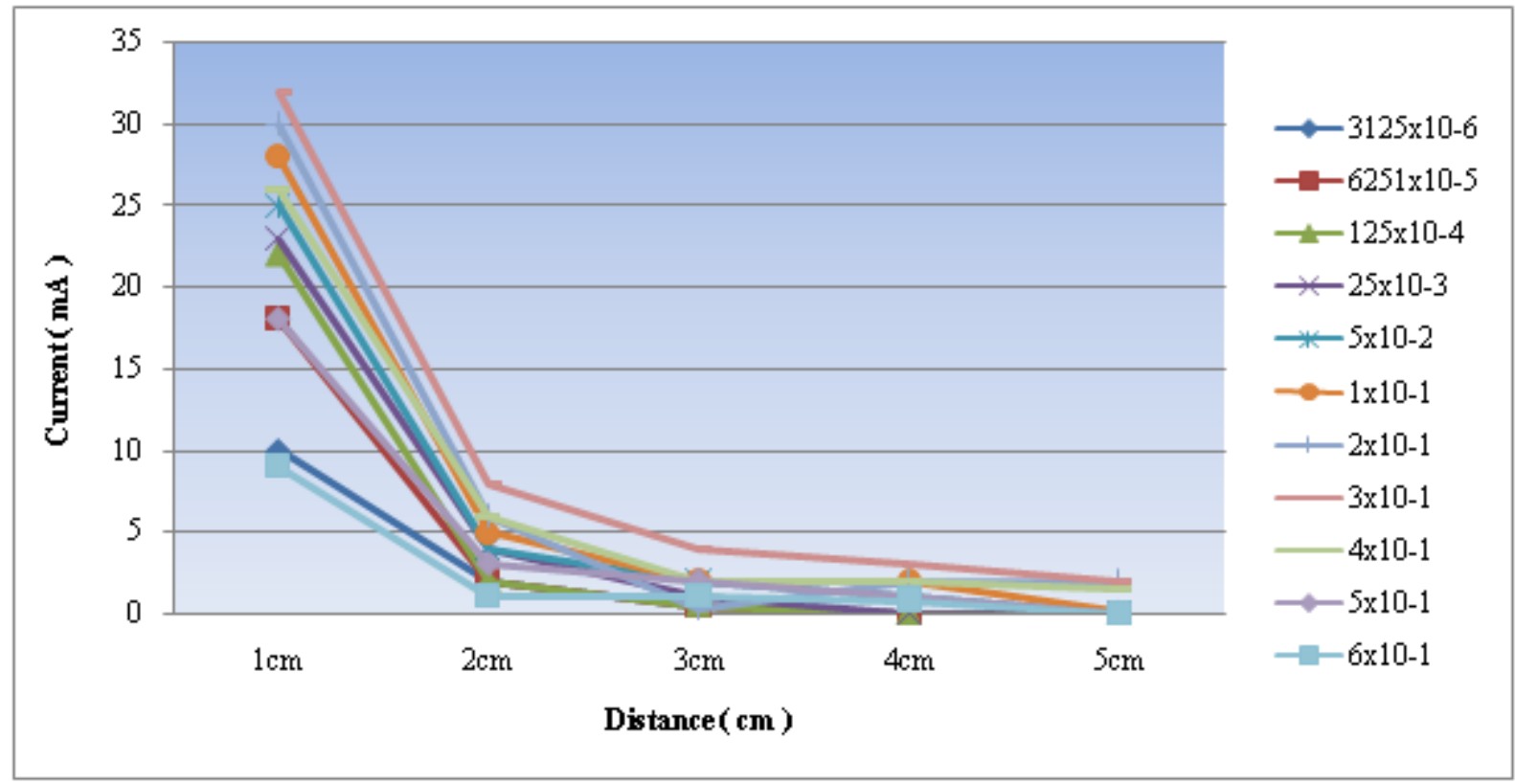

Figure 4: The Variation of current (mA) with different distances 0f aCapacitor for different concentrations of the gum Arabic solution after the addition of $\mathrm{NaCl}(2 \%)$

Concentration $(\%)$ 


\section{International Journal of Science and Research (IJSR) \\ ISSN (Online): 2319-7064}

Index Copernicus Value (2013): 6.14 | Impact Factor (2014): 5.611

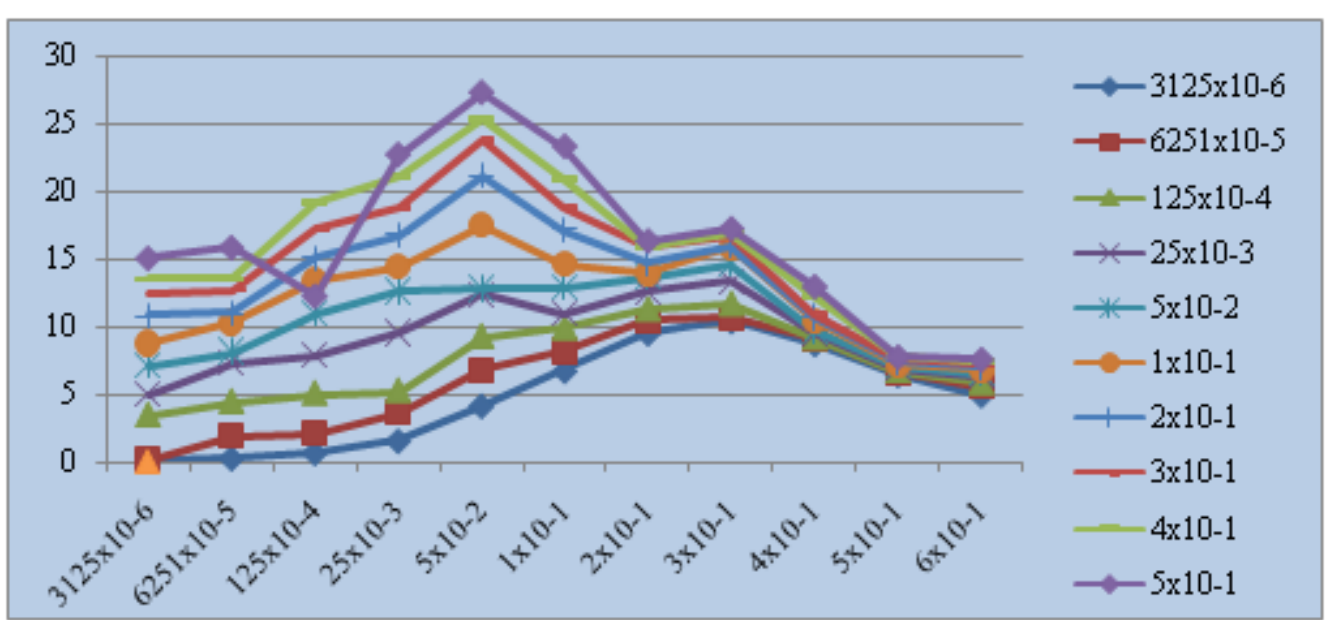

Figure 5: The Variation of Conductivity $(\mathrm{mS})$ with different concentrations of the gum Arabic solution when different amounts of $\mathrm{NaCl}(2 \%)$ are added.

Figure $(6,8,10,12,14)$ The Variation of current $(\mathrm{mA})$ with Potential difference (V) for different concentrations of gum Arabic solution when the distance between Capacitor plates is $(1,2,3,4,5 \mathrm{~cm})$ respectively.

Fig $(7,9,11,13,15)$ The Variation of current (mA) with Potential difference (V) for different concentrations of gum Arabic solution after the addition of $\mathrm{NaCl} 2 \%$ when the distance between Capacitor plates is $(1,2,3,4,5 \mathrm{~cm})$ respectively.

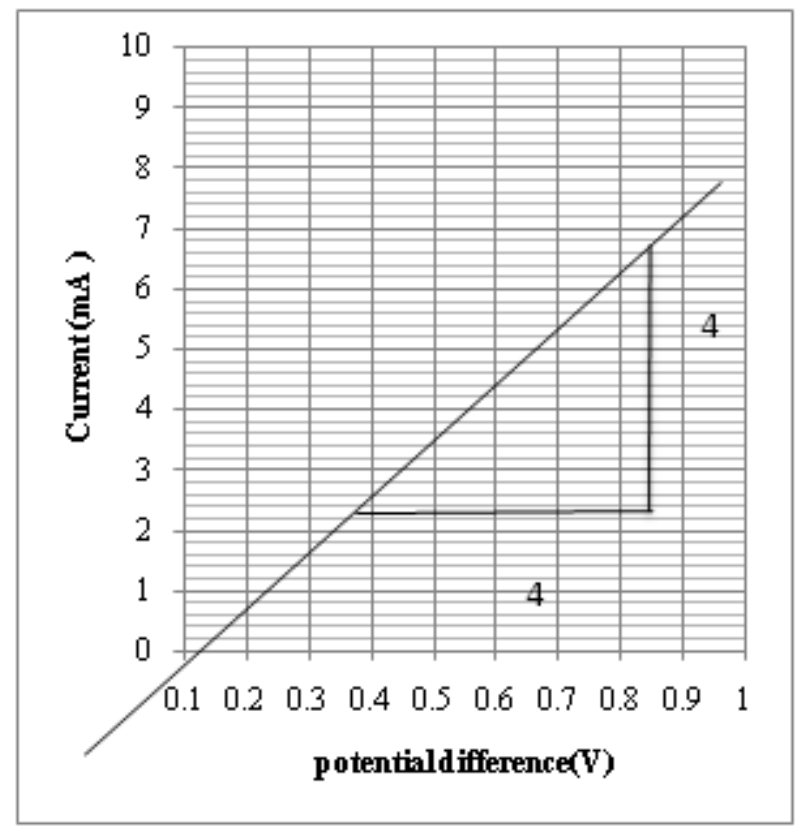

Figure 6:

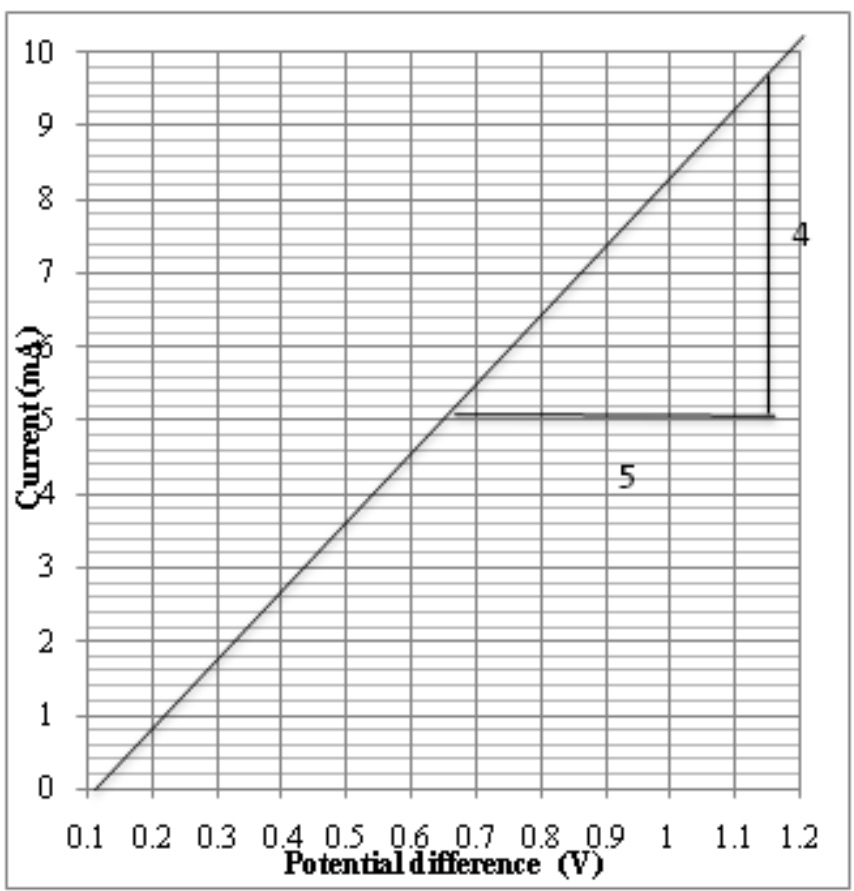

Figure 7: 
International Journal of Science and Research (IJSR)

ISSN (Online): 2319-7064

Index Copernicus Value (2013): 6.14 | Impact Factor (2014): 5.611
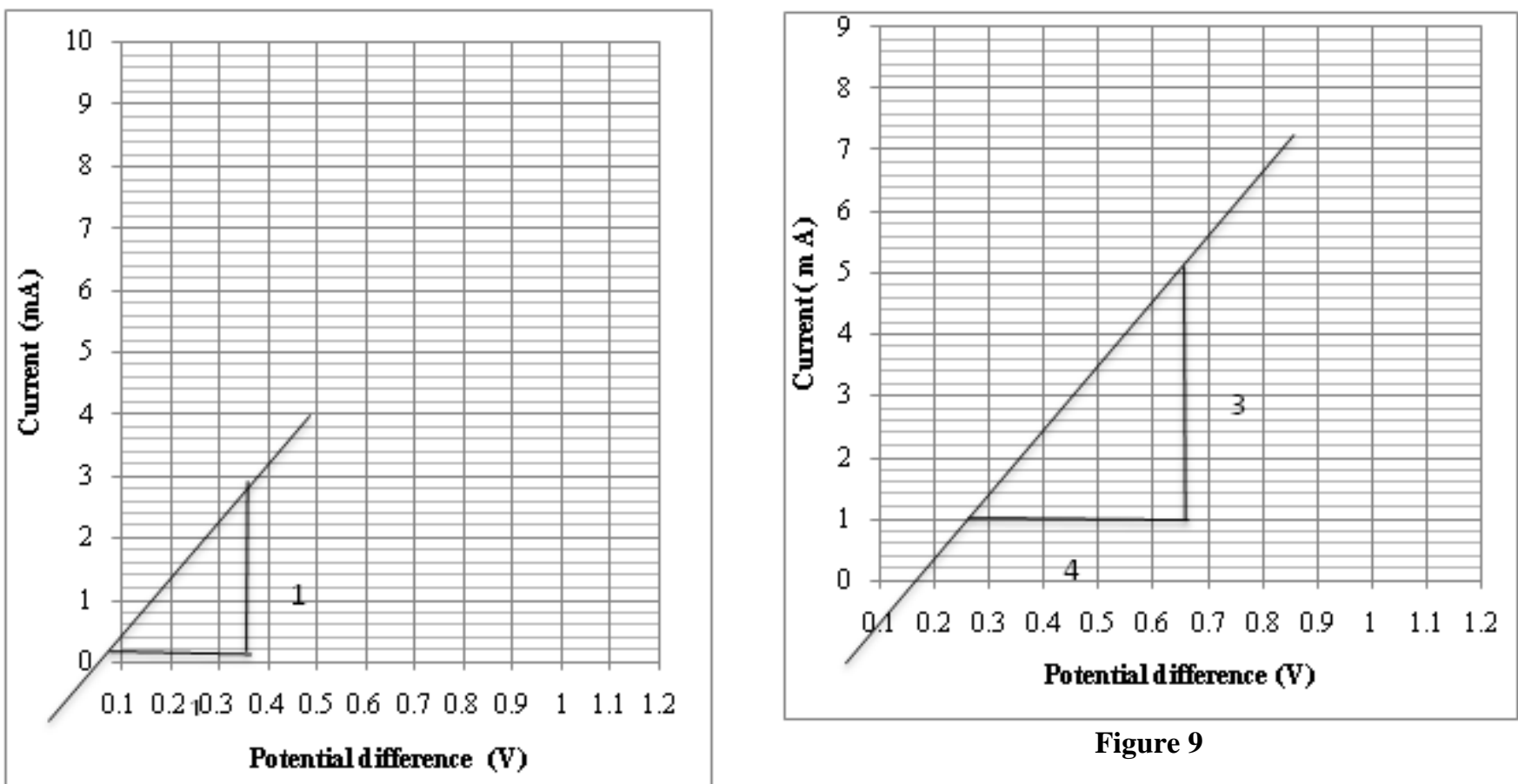

Figure 9

Figure 8:

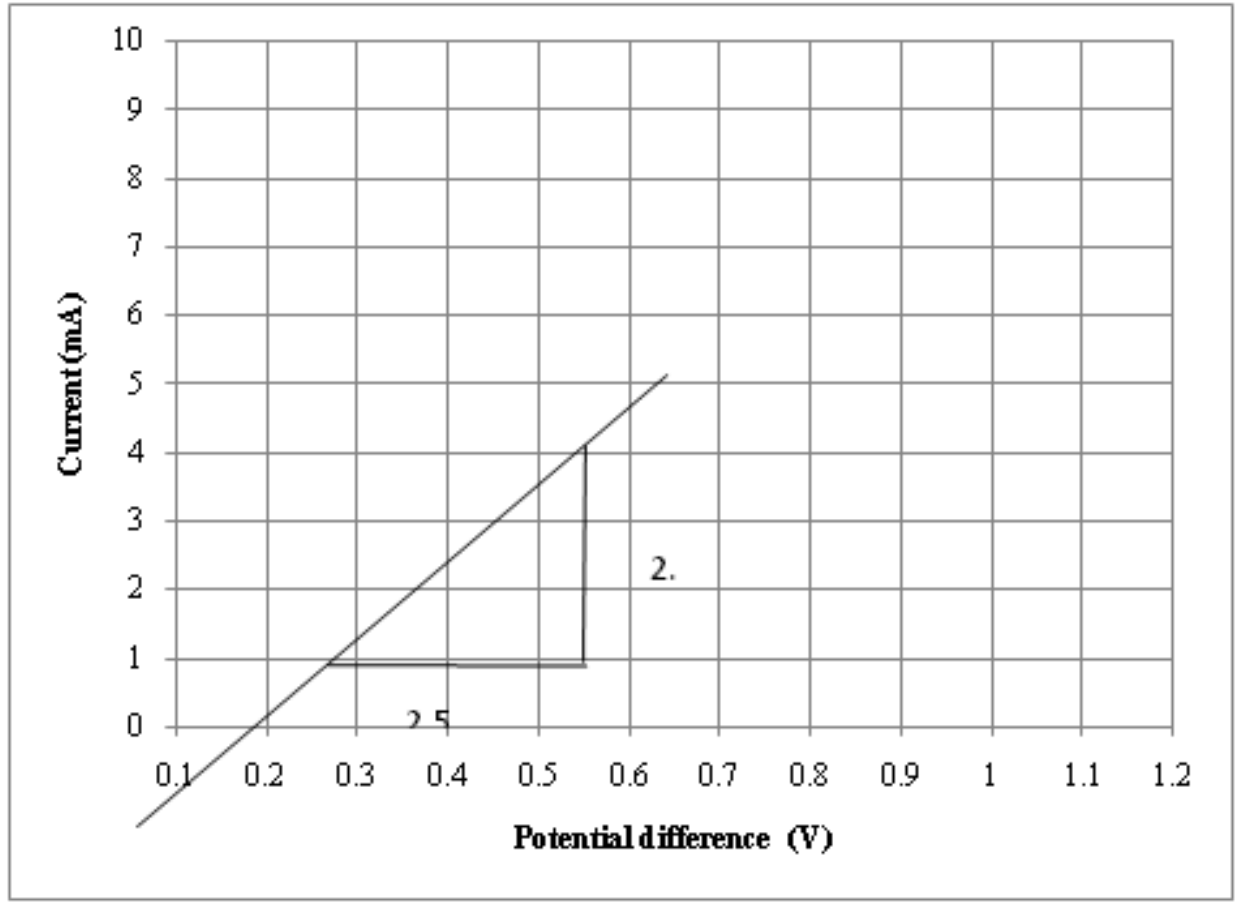

Figure 10

Volume 5 Issue 2, February 2016

www.ijsr.net 
International Journal of Science and Research (IJSR)

ISSN (Online): 2319-7064

Index Copernicus Value (2013): 6.14 | Impact Factor (2014): 5.611

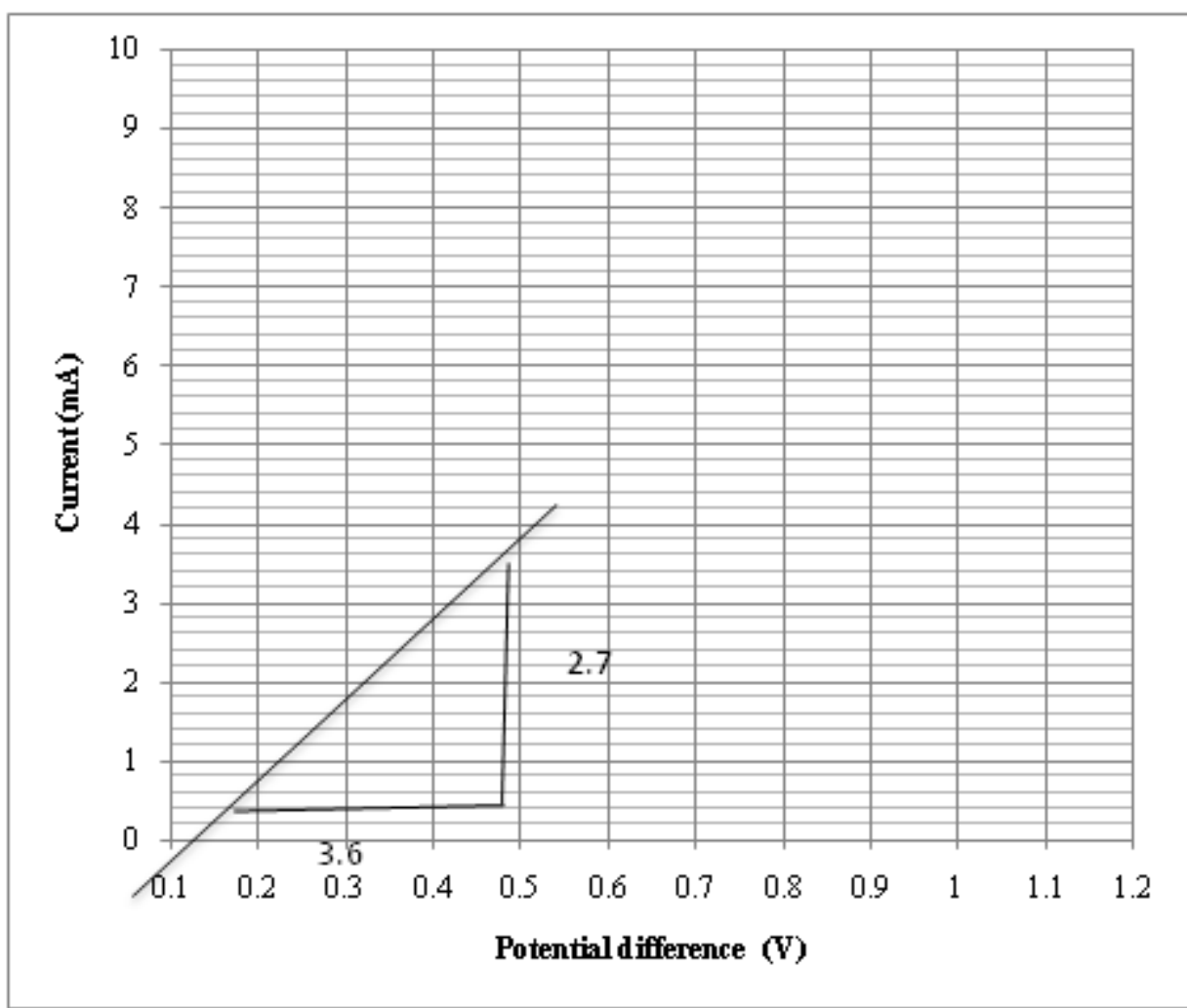

Figure 11

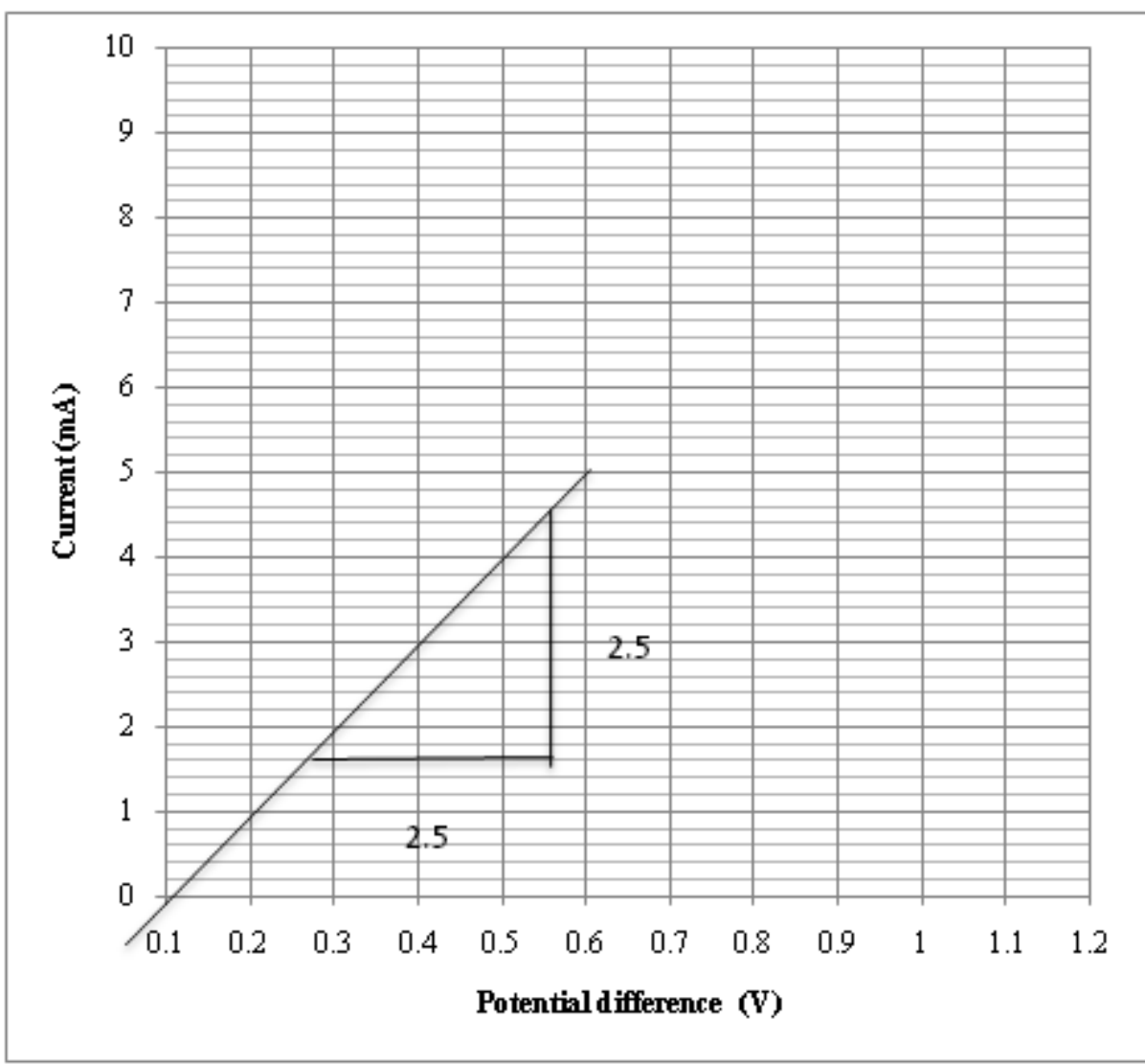

Figure 12

Volume 5 Issue 2, February 2016

www.ijsr.net 
International Journal of Science and Research (IJSR)

ISSN (Online): 2319-7064

Index Copernicus Value (2013): 6.14 | Impact Factor (2014): 5.611

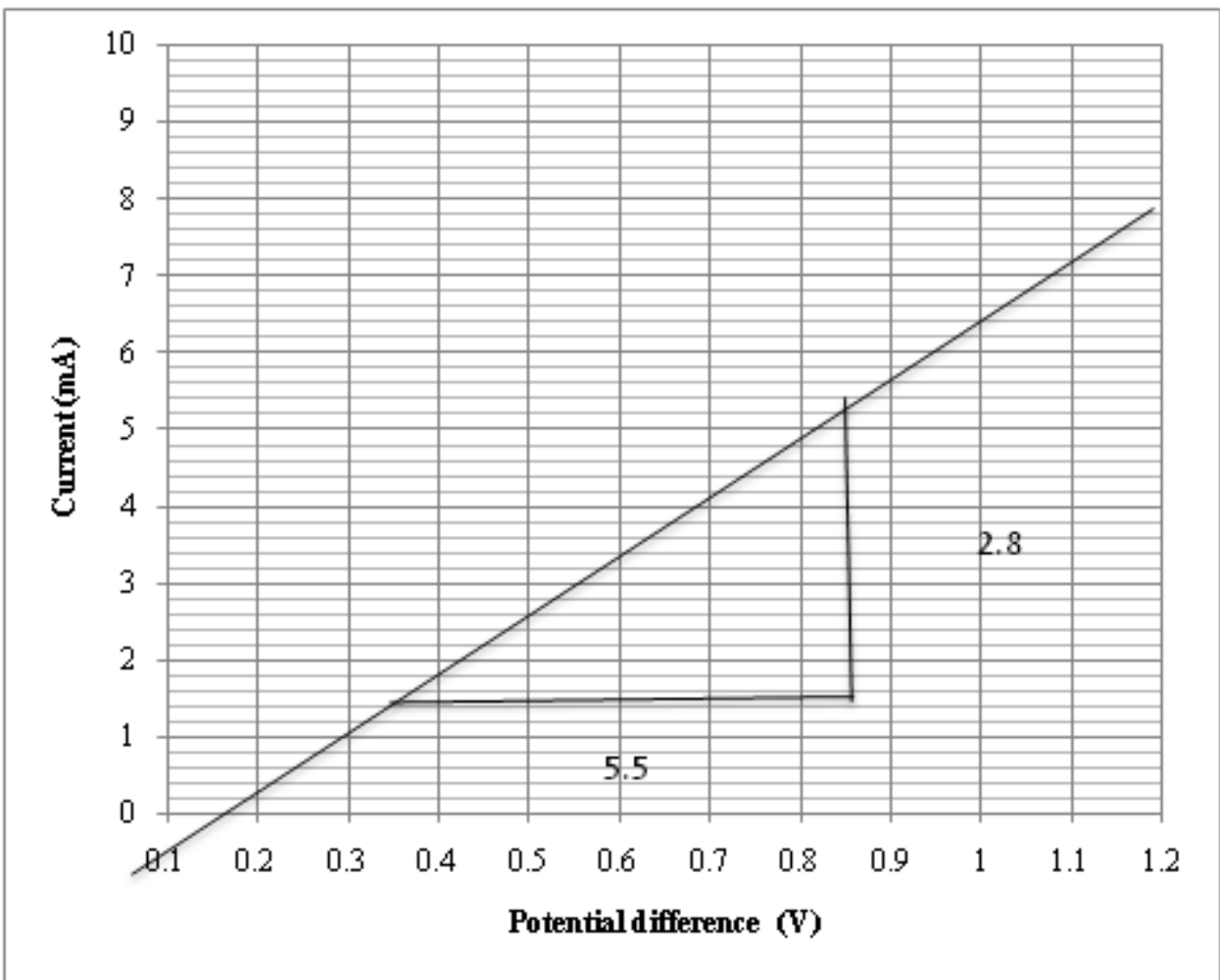

Figure 13

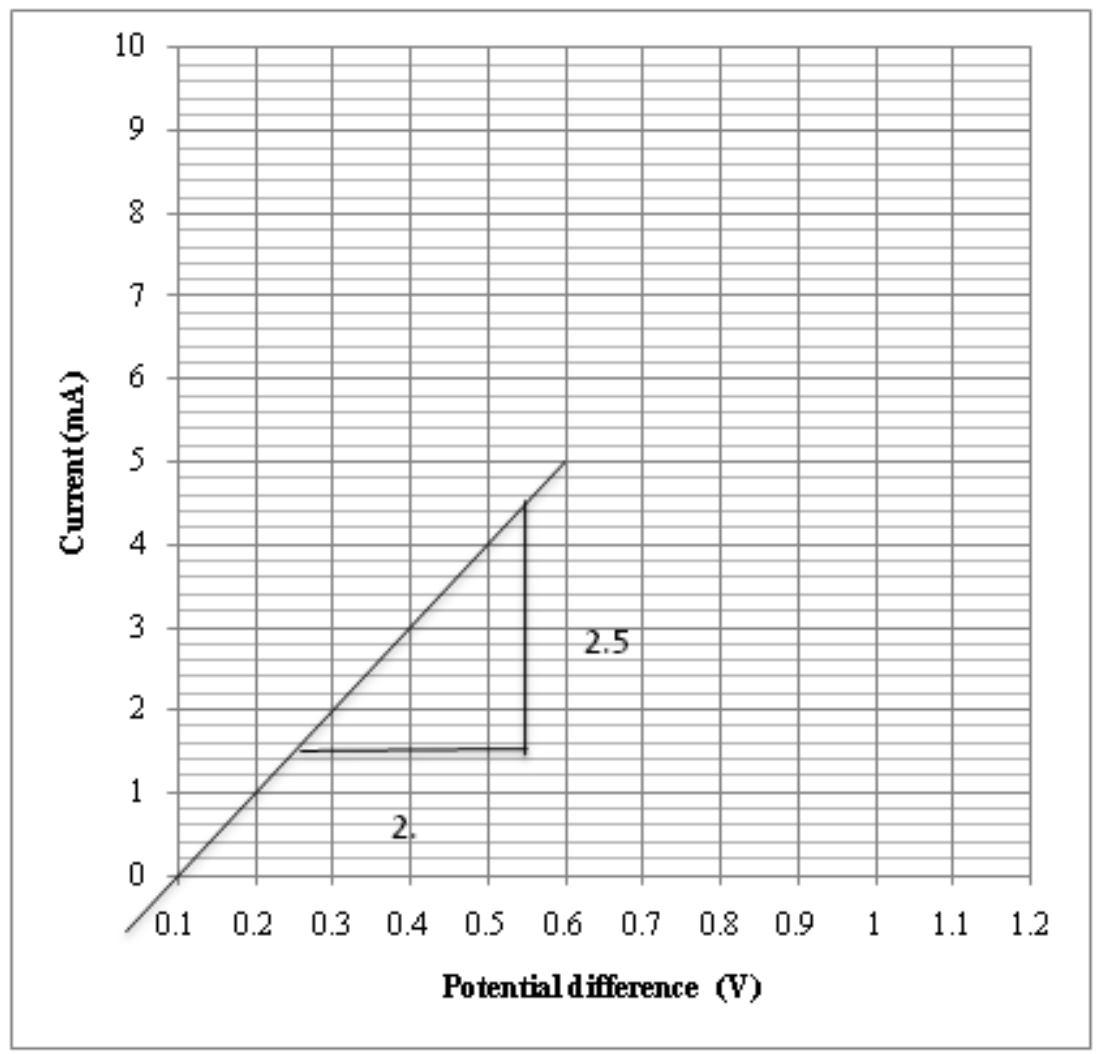

Figure 14

Volume 5 Issue 2, February 2016

www.ijsr.net 
International Journal of Science and Research (IJSR)

ISSN (Online): 2319-7064

Index Copernicus Value (2013): 6.14 | Impact Factor (2014): 5.611

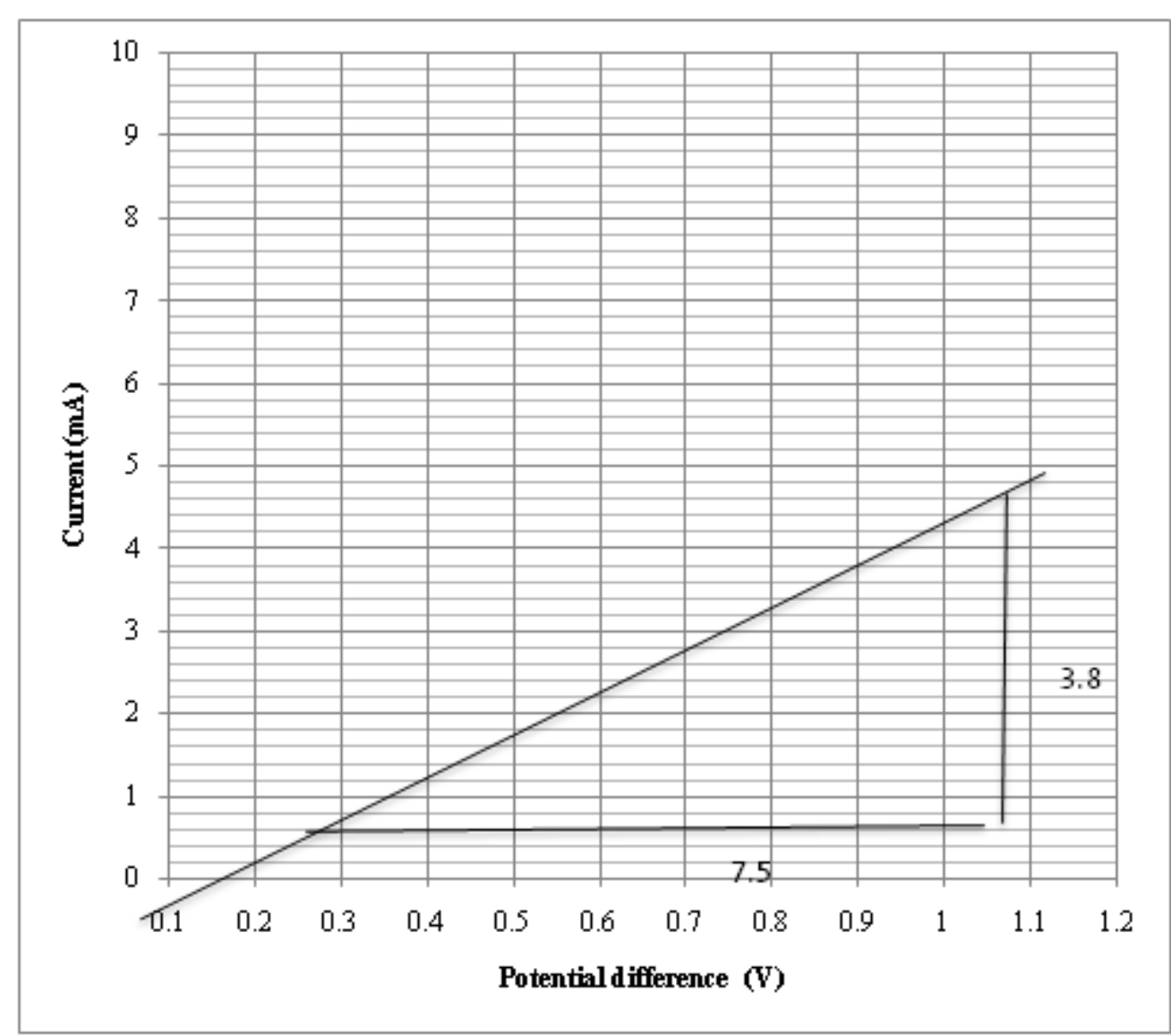

Figure 15

\section{Discussion}

From fig (1) the conductivities increase with temperature and concentrations of the gum solutions to reach maximum at the concentration of $0.3 \%$ and then decrease, these finding different form the usual behavior .

From the fig (2), it's clear that no current could pass, then the concentration of the gum solution is very low especially at higher temperature.

The conductivity is maximum when the concentration of gum solution is about $0.3 \%$ then the conductivity decreases when the concentration increases or when the temperature increases.

Fig (3) show that the passed current through the capacitor containing different concentration of gum solution decreases with the increasing of the distance between the capacitor plates.

The maximum current shown when the concentration of $0.3 \%$ and the distance between the capacitor plates is $1 \mathrm{~cm}$. Figures (3), (4), (5) show that addition of an electrolyte $(\mathrm{NaCl})$ solution generally increases, this is normal behavior. Figures (6) to (15) show that increasing the potential difference across the capacitor increase the amount of the current that could pass when the distance between the capacitor plates, the concentration of the gum solution and the mount of the added electrolyte are fixed.

Finally the permittivity of gum sample measured before and after adding $\mathrm{NaCL}$ solution (2\%) agrees with the electrical calculations when the frequency, amount of current, potential difference, capacitive reactance, area of the plates and the distance between the two plates of the parallel capacitor known.

\section{Conclusions and Recommendation}

The researcher recommends more researches in this field to make use of gum Arabic as materials that can be entered in technique of modern electronic manufacture instead of the routine using of gum in food, also the researcher recommends the use of direct current on the sun research to reveal the properties and possibility of using gum Arabic in transistors, solar cells, and different types of capacitors with different capacity and use of gum Arabic in its solid state or crystals.

\section{References}

[1] Anderson, D.M.W. Hirst, E.L and Stoddart, J.F (1966): J.Chem.Soc. (C)(1959): The Composition of Acacia Gum Exudates.

[2] Anderson, D.M.W. and Karamalla, K.A.(1966): J.Chem. Soc .(C) .

[3] Anderson, D.M.W. and Dea,I.C.M. (1968): Carbohydrate .Res .6. $104-110$.

[4] Anderson, D.M.W. and Dea, I.C.M. (1969): Carbohydrate .Res .10, 151-164.

[5] Anderson, D.M.W. and Munro, C.A. (1970): Carbohydrate. Res. 12, 9- Anderson, A.W.J ., Brydon,W.J.,Fastwood, M.A.M., Cdougall, F.J.and D.M.W., (1983): Food Addit . Contamination., 2 (1) 33. 


\section{International Journal of Science and Research (IJSR) \\ ISSN (Online): 2319-7064}

Index Copernicus Value (2013): 6.14 | Impact Factor (2014): 5.611

[6] Anderson, D.M.W., and Howlett, J.F. and Mcnab, C.G.A. (1985): Food Addit . Contamination . 2, 159164.

[7] Anderson, D.M.W.(1986): Food Addit. Contamination. 3,225.

[8] AOAC (1984): Association of Official Griculture Chemisits Official Method of Analysis . $14^{\mathrm{TH}} \mathrm{Ed}$. Washington.

[9] Barrow, G.M.(1983): Phhhysic Chem.P 570, 71-572..

[10] Cromer, A.H. (1974): Physics for the Life Sciences P.345-346-347..

[11]Erskin, A.J. and Jones, J.K.N. (1956): Canad.J.Chem.34, 821.

[12] European, Pharmacopoeia(1990): Second Edition. Maison neuve, C.A. Sainte Ruffine,P:307.

[13]FAO.(1990): Food and Nutrition Paper No 49 Rome.

[14]FAO.(1990): Food and Nutrition Paper No 44.

[15]Finar, I.L. (1967): Organic Chemist Stereo Chemistry and the Chemist of Natural Products.P 285.

[16] Hassan, H.A.(2002): M.Sc. Thesis University of Sudan for Science and Technology

[17] Harris, J.P.., Henry,J.R.., Blakeney, B.A.and Brace, S.A. (1984): carbohydrate .Res.127, 59,73.

[18] Howes, F.N.(1949): Vegetable Gum and Resins.Published by Chronica Botanica Company

[19] Karamalla,K.A (1995):ph.D. Theses, University of Edinburgh.

[20] Mantel, C.L ( 1947) : The Water Soluble gums. Reinheld New York.

[21] Mbuna, J.J.( 1997) : M.SC Thesis, University of Dar Elsallaam.

[22] Siddig,N.E.( 1996): M.SC Thesis, University of Khartum.

[23] Smith, F and Montrgomcry, R. ( 1959):The Chemist of Plant Gums and Mucilages . 